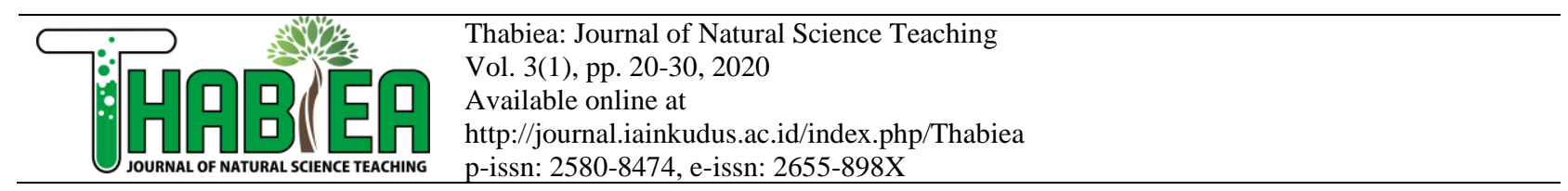

\title{
The influence of educational comics on the concept of static electricity toward student's learning outcomes and communication skills
}

\author{
Dewi Dewantara \\ Physics Education, Universitas Lambung Mangkurat, Indonesia \\ *Correspondence: dewantarafisika@gmail.com
}

\begin{tabular}{|c|c|}
\hline & Abstract \\
\hline $\begin{array}{l}\text { Key word: } \\
\text { Educational Comic } \\
\text { Static Electricity } \\
\text { Learning Outcomes } \\
\text { Communication Skill }\end{array}$ & $\begin{array}{l}\text { This article aims to investigate the effect of educational comics about static electricity } \\
\text { on student learning outcomes and student communication skills. The research subjects } \\
\text { were students of the Physics Education Study Program at Lambung Mangkurat } \\
\text { University Academic Year 2019/2020. The research design used was one group } \\
\text { pretest-posttest design. Student learning outcomes data obtained from student learning } \\
\text { outcomes tests. Data on students' communication skills were obtained from } \\
\text { observation sheets. The results of the pretest and posttest were then tested for } \\
\text { normality and homogeneity which showed that the data were normally distributed and } \\
\text { the variants were homogeneous. Then, the data were tested for the significance of } \\
\text { differences using the paired t-test. The Sig (2-tailed) test results show a number below } \\
\text { 0.05 so there is a significant difference between the pretest and posttest results. The } \\
\text { effectiveness of the use of educational comics is tested using the N-gain test to } \\
\text { determine its effectiveness category. The N-gain test result is } 0.705 \text { so the N-gain test } \\
\text { result is categorized high. Overall student communication skills are included in both } \\
\text { categories. This result is supported by students' responses to educational comics which } \\
\text { are overall well categorized. This article concludes that there is an educational comic } \\
\text { effect on static electricity towards student learning outcomes and communication } \\
\text { skills. }\end{array}$ \\
\hline
\end{tabular}

To cite this article:

Dewantara, D. (2020). The influence of educational comics on the concept of static electricity toward student's learning outcomes and communication skills. Thabiea: Journal of Natural Science Teaching, 3(1), 20-30.

\section{Introduction}

In the industrial revolution 4.0 era, 21 st-century skills that reflected $4 \mathrm{C}$ namely collaboration, communication, critical thinking, and creative thinking were considered very important, especially with the increasing demands for skilled and skilled modern workers. (Ridwan, 2019). Communication is a social interaction between people who share their ideas (Marlina \& Jayanti, 2019). This skill is closely related to the skill of someone expressing their opinions in a way that is good and understandable (Susanti \& Risnanosanti, 2019). Learning that sharpens communicative skills is learning that puts forward the activity of exchanging opinions, presenting an idea, or discussing activities (Ridwan, 2019). Communication is a student's skill in expressing all his thoughts both verbally and in writing to develop his abilities in learning activities and face the challenges of the 21st century (Raniah et al., 2018). Through communication, ideas can be rejuvenated, enhanced, discussed, and developed. The communication process can also help build meaning, provide ideas, and publish ideas (Yulian, 2018). 
Communication skills need to be trained in learning that adapts to current educational developments. Educational development and innovation can develop through the development of science and technology, one of which is learning media (Annur, Wati, Wahyuni, \& Dewantara, 2018; D Dewantara, Febrianti, Wati, \& Mastuang, 2019; Hartini, Misbah, Dewantara, Oktovian, \& Aisyah, 2017; Mahtari, Wati, Hartini, Misbah, \& Dewantara, 2020; Misbah, Dewantara, Hasan, \& Annur, 2018; Utami, R. Sumarni, W. Habibah, 2017). Learning media play an important role in achieving maximum learning outcomes (Fadhila \& Widodo, 2019). Learning media are used specifically to improve communication skills, one of which is comic media (Yulian, 2018). There is still not too much research on educational comics and their implementation in learning (Tribull, 2017).

Comics can be developed into educational comics that can be used to assist students in understanding lessons (Fadhila \& Widodo, 2019). Physics education comics can be developed in learning on various physics materials (Nikmah, Haroky, Jumadi, Wilujeng, \& Kuswanto, 2019). Educational comics can also be used to foster positive student attitudes and can be used as alternative guidebooks (Putri, Fida, \& Wasis, 2018). In various previous studies, it is clear that the purpose of utilizing educational comics is to improve student achievement through images (Kamil, Komariah, \& Yuliana, 2017).

This research uses educational comics on static electricity in physics learning. This research was conducted on static electricity material taught to prospective physics teacher students in high school physics studies. The development of educational comics on static electricity was tested for the influence of learning. Therefore, This article aims to investigate the effect of educational comics about static electricity on student learning outcomes and student communication skills. The research subjects were students of the Physics Education Study Program at Lambung Mangkurat University Academic Year 2019/2020.

\section{Method}

The research design used was one group pretest-posttest design. The research subjects were students of the Physics Education Study Program, FKIP Lambung Mangkurat University odd semester 2019/2020 Academic Year.

The results of the pretest and posttest were tested whether there were significant differences between the pretest and posttest values using the paired sample t-test. Significance value (2-tailed) $<0.05$ indicates a significant difference between the results of the pretest and posttest when using educational comics that were developed. Significance value (2-tailed)> 0.05 indicates there is no significant difference between the results of the pretest and posttest when using educational comics on static electricity developed.

If the paired sample t-test results indicate a significant difference between the pretest and posttest values, then proceed with the $\mathrm{N}$-gain test. Normalized gain $(\mathrm{N}$-gain) equations are used to find out how the effectiveness category of educational comics in static electricity is viewed from student learning outcomes. Previously conducted a normality test first to find out whether the data is normally distributed or not. Requirements for normally distributed data are if the significant value obtained is greater than 0.05 .

After obtaining the value of normalized gain (N-gain), the criteria for the effectiveness of educational comics on static electricity can be seen in the following Table 1. 
Tabel 1. Criteria for the effectiveness of educational comics on static electricity

\begin{tabular}{ll}
\hline $\boldsymbol{N}$-gain Score & Criteria \\
\hline$(\langle g\rangle) \geq 0,7$ & High \\
$0,7\rangle(\langle g\rangle) \geq 0,3$ & Medium \\
$(\langle g\rangle)<0,3$ & Low \\
\hline
\end{tabular}

(Hake, 1998)

Student communication skills are collected from the questionnaire assessment of student communication skills. The questionnaire was analyzed and the mean values obtained for each indicator. Then, the data is matched with the categories in the following Table 2.

Table 2. Student Communication Skills Assessment Categories

\begin{tabular}{ll}
\hline Interval & Criteria \\
\hline $4,2<X \leq 5$ & Very skilled \\
$3,4<X \leq 4,2$ & Skilled \\
$2,6<X \leq 3,4$ & Enough \\
$1,8<X \leq 2,6$ & Poor skilled \\
$1<X \leq 1,8$ & Not skilled \\
\hline
\end{tabular}

(Widoyoko, 2016)

Student responses were collected from student questionnaire responses. The questionnaire was analyzed and the mean values obtained for each indicator. Then, the data is matched with the categories in the following Table 3.

Table 3. Category of Student Responses

\begin{tabular}{lc}
\hline \multicolumn{1}{c}{ Interval } & Criteria \\
\hline $4,2<X \leq 5$ & Very good \\
$3,4<X \leq 4,2$ & Good \\
$2,6<X \leq 3,4$ & Enough \\
$1,8<X \leq 2,6$ & Poor \\
$1<X \leq 1,8$ & Not good \\
\hline
\end{tabular}

(Widoyoko, 2016)

\section{Results and Discussion}

The product produced from this research is educational comics on static electricity material in improving student learning outcomes and communication skills. In the comic (Figure 1.), there is a conversation between two students who learn from one another about static electricity. Most of the conversations are deliberately left blank to be filled by students from various reference sources they have. Next, students will present the comic in turn to see how students' communication skills are. 

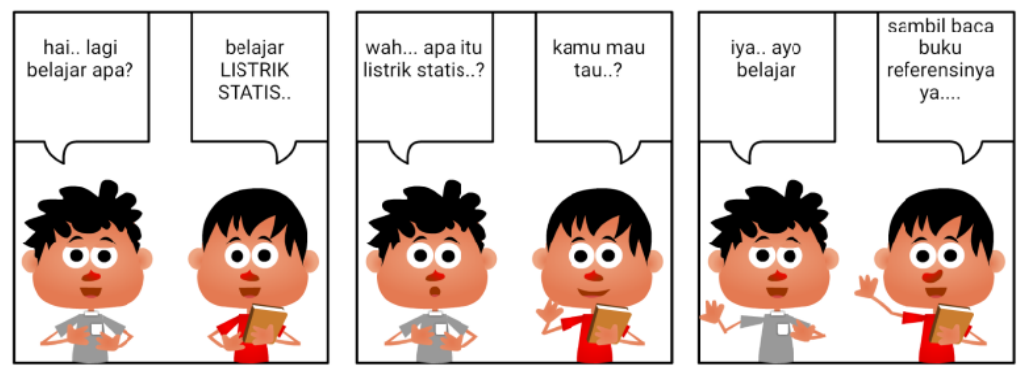

Figure 1. Display of Educational Comic

\section{Student learning outcomes}

The results of the comparison of the average pre-test and post-test values can be seen in Figure 2. The figure shows that the posttest value is higher than the pretest value.

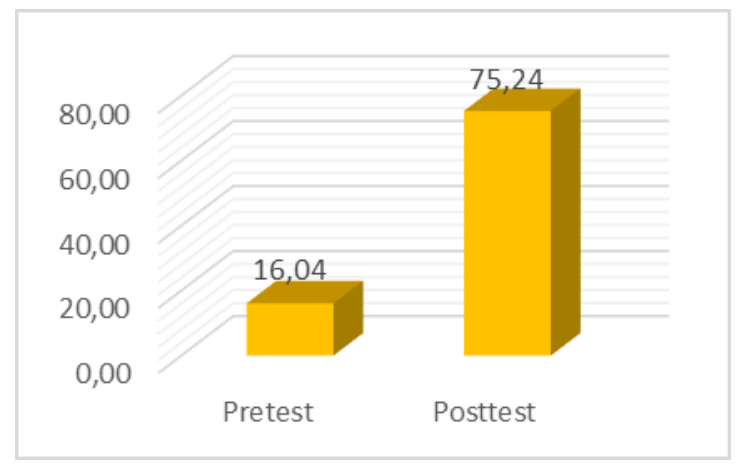

Figure 2. Average pretest and posttest

The results of the pretest and posttest were then tested for normality and homogeneity which showed that the data were normally distributed and the variants were homogeneous. Then, the data is tested for the significance of the difference using the paired t-test. Table 4 shows the results of the test. Sig value (2-tailed) shows a number below 0.05 . Thus there is a significant difference between the results of the pretest and posttest when using learning comics on static electricity developed.

Table 4. Result of paired t-test

\begin{tabular}{ccc}
\hline $\mathbf{t}$ & df & Sig. (2-tailed) \\
\hline 46.887 & 55 & .000 \\
\hline
\end{tabular}

The effectiveness of the application of blended learning is tested using the $\mathrm{N}$-gain test to determine its effectiveness category. The $\mathrm{N}$-gain test result is 0.705 . Thus the $\mathrm{N}$-gain test results are categorized as high. This is consistent with previous research that educational comics are suitable for use as effective learning media (Krishnan \& Othman, 2016). Educational comics effectively fulfill student learning completeness (Hidayah \& Fathimatuzzahra, 2019). Comics are more effective in maintaining the knowledge students have gained (Zhang-Kennedy, Baig, \& Chiasson, 2017). Comics are also able to increase student interest and understanding (B. S. Chung, Park, Kim, Cho, \& Chung, 2016). Other research also shows that classes using educational comics are more effective than control 
classes (Munawwaroh, Priyono, \& Ningsih, 2018).

The use of comics as a teaching and learning tool is very popular in Western countries, especially in developed countries (Krishnan \& Othman, 2016). Educational comics are effective in terms of communicating scientific concepts (Lin \& Lin, 2016). In the learning process, educational comics have been very helpful in facilitating the implementation of learning (Haroky, Nikmah, Wilujeng, Jumadi, \& Kuswanto, 2019). Also, educational comics can function as intermediaries in delivering material so students can understand the material easily (Fadhila \& Widodo, 2019).

The development of physics education comics has become an innovation in learning that can be used anywhere and anytime (Nikmah et al., 2019). Educational comics are comics that tell about the subject matter or matters relating to education. Comic education has two main functions as a medium of entertainment as well as a means to convey educational goals to readers (Putri et al., 2018). Comics are media that can make students learn effectively and can be applied easily in learning activities (Kamil et al., 2017).

Educational comics that are used appropriately will make learning more meaningful (Krishnan \& Othman, 2016). This educational comic can be used in teaching science (Maryani \& Amalia, 2018). Comics have proven useful in various fields of learning (Muzumdar, 2016). Students' conceptual understanding is taken from practice questions in the android comic media that students must solve in groups (Haroky et al., 2019).

\section{Student Communication Skills}

Students' communication skills are reflected in the following indicators:(1) Oral Communication; (2)Discerns Intent; (3) Receptive Communication: Listens, Reads, Views; (4) Communicates Clearly for a Purpose; (5) Uses a full range of resources to express ideas; dan (6) Presentation Skills (Greenstein, 2013). Oral Communication related to Clarity, speed, volume, and articulation are all strong and strengthen the course of communication. Discerns Intent is concerned with the skill of identifying and interpreting the aims and objectives of open and implicit messages. Also able to draw logical conclusions. Receptive Communication is related to the skill to distinguish between facts and opinions. Also able to identify and summarize the main ideas. Also able to identify various supporting materials from various points of view. Communicates Clearly for a Purpose, related to the skills to understand the purpose of communication. Then organize and present information to meet these understood goals. Use a full range of resources to express ideas related to the skills to choose and use various combinations of communication resources that suit the topic and purpose independently. Presentation Skills relate to readiness, accuracy, and responsiveness in presentations. Also, skills in responding to the audience's expression/gesture by adjusting the tone, expression, and steps. 


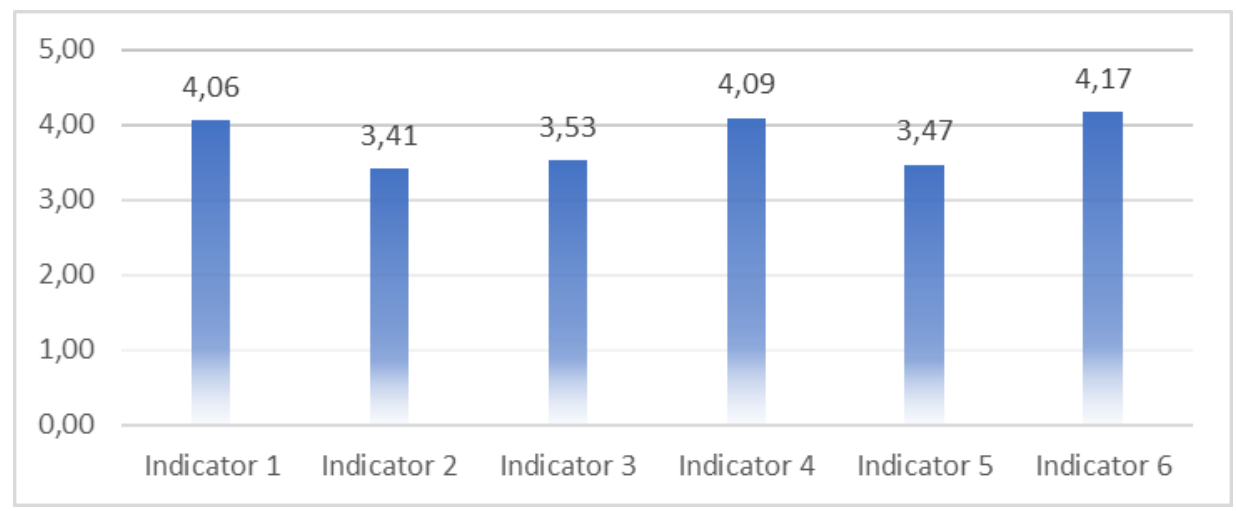

Figure 3. Result of Student Communication Skills

The results of student communication skills can be seen in Figure 2. Oral Communication has an average of 4.06 so it has a skilled category. Discerns Intent has an average of 3.41 so it has a skilled category. Receptive Communication: Listens, Reads, Views have an average of 3.53 so they have a skilled category. Communicates Clearly for a Purpose has an average of 4.09 so that it has a skilled category. Accessing a full range of resources to express ideas has an average of 3.47 so that it has a skilled category. Overall, students' communication skills are categorized as skilled.

Through educational comics, students are invited to discuss and take turns presenting the contents of the comics. In line with previous research, by using educational comics students can discuss with each other (Haroky et al., 2019). Communication skills have been widely identified in many different countries as competencies needed in the twenty-first century (Y. Chung, Yoo, Kim, Lee, \& Zeidler, 2016). Communication skills are one of the basic skills that students need to master (Prabowo \& Ariani, 2018). This is because communication skills are important skills for prospective teachers (Hardianti, Taufiq, \& Pamelasari, 2017).

Communication is an important component in the learning process, including learning (Yulian, 2018). The communication process is important in enhancing effective interpersonal skills (Batool, Nadeem, \& Asif, 2018). In learning science, one of the competencies students must possess is being able to communicate their various information, ideas, and opinions effectively (Hardianti et al., 2017). Information, ideas, and opinions obtained by students in learning need to be shared with others as an implementation of knowledge dissemination (AlFarisi, Tjandrakirana, \& Agustini, 2018).

\section{Student Response}

The response questionnaire consisted of two aspects: performance and benefits (Dewi Dewantara, Mahtari, Misbah, \& Haryandi, 2019; Misbah et al., 2018). The student responses were collected through a questionnaire that provided with ranks of very good, good, enough, poor, and not good. Overall, student responses had a mean value of 4.17. Based on Table 2, students' responses to learning comics on static electricity material are good. 


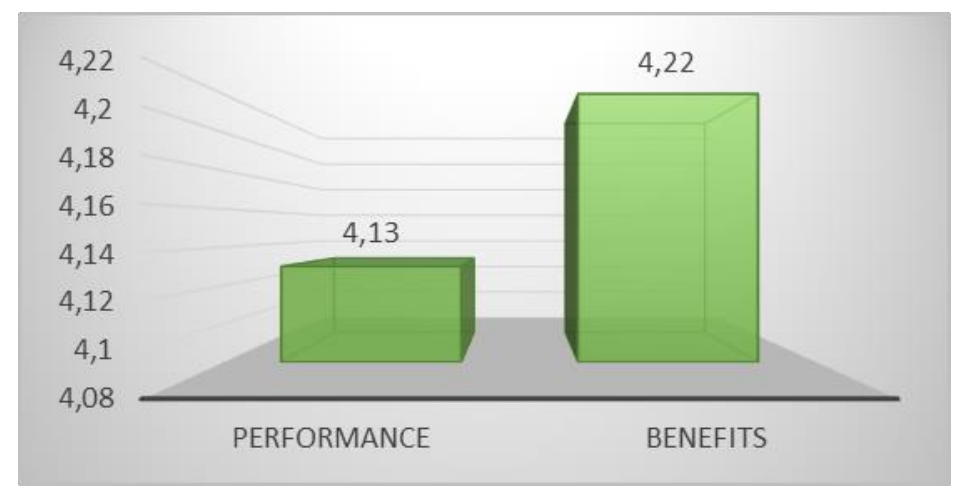

Figure 4. Result of student responses

The statement items on the student response questionnaire about performance are as follows: (a) The display of learning comics on static electricity is very clear and easy to understand; (b) By learning comics on static electricity material, obtaining knowledge transfer processes flexibly and independently; and (c) learning comics on static electricity make it easy for me to practice communication skills. The student response to the performance aspect is 4.13. Based on Table 2, this has a good category.

In the aspect of benefits, student responses showed a very good category. The statements on the student's questionnaire about the benefits are as follows: (a) Using learning comics on static electricity material is possible in understanding the material; (b) learning comics on static electricity improve student learning performance; (c) learning comics on static electricity are very useful in the learning process; (d) Ease of using learning comics on static electricity; (e) Ease of practicing communication skills; (f) learning comics on static electricity attract students' attention in learning;and (g) learning comics on static electricity material enables students to get feedback faster. The student response to the performance aspect is 4.22 . Based on Table 2, this has a very good category.

The existence of a teacher has a major role in the success of learning. This also relates to learning media and how innovative and intelligent the teacher is in designing learning, so that learning becomes interesting and enjoyable. Educational comics are expected to contribute to the world of education (Ariyanto \& Laksana, 2018). Although many variations of learning media have been used, some of them have weaknesses so there are still need to be added alternative learning media that are more innovative and able to increase student motivation and learning outcomes, such as educational comics (Munawwaroh et al., 2018).

Student responses related to their responses to their performance and benefits. The results of previous studies indicate that educational comics are interesting because learning to use comic media is a new learning experience for students (Nikmah et al., 2019). The use of educational comics can activate students physically and mentally. When the trial is done the classroom atmosphere becomes more pleasant (Daulay, Ananda, Anwar, \& Fatimah, 2019).

Combining text with visual representation while teaching students contributes to increasing students' attention and participation because of their novelty (Arini, Choiri, \& Sunardi, 2017). Educational comics serve as an effective tool to make their students interested in reading (McGrail, Rieger, Doepker, \& McGeorge, 2018). Activities in class go well and comics can motivate students during the learning process (Kamil et al., 2017). The hope of developing educational comic media is that students interpret the learning process 
that can motivate and encourage creativity and intelligence in learning through fun media (Fadhila \& Widodo, 2019). Students enjoy learning with comics because it is a new experience for them. The colorful comic pages make it more interesting, most students say they are excited because it's not a boring textbook full of text (Arini et al., 2017).

\section{Conclusion}

This article concludes that there is an educational comic effect on static electricity towards student learning outcomes and communication skills. This can be seen from the learning outcomes of students who experienced significant differences between pre-test and post-test and the $\mathrm{N}$ gain test which was categorized as high. Quality is also seen from the communication skills of students who are in good categories, as well as student responses that are also categorized as good. The implementation of learning by using learning comics on static electricity material that is developed can facilitate teaching and training students' communication skills. Further research is needed to find out the effectiveness of learning comics on static electricity material on the abilities and skills of other students. In other lectures, learning comics can also be developed on static electricity that aims to improve learning outcomes and train students' communication skills.

\section{References}

Al-Farisi, B. L., Tjandrakirana, \& Agustini, R. (2018). Drilling Students' Communication Skill through Science, Environment, Technology, and Society (SETS)-Based Learning. Journal of Physics: Conference Series, 947(1). https://doi.org/10.1088/1742-6596/947/1/012071

Annur, S., Wati, M., Wahyuni, V. J., \& Dewantara, D. (2018). Development of Simple Machines Props Using Environmentally Friendly Materials for Junior High School. In 6th International Conference on Educational Research and Innovation (ICERI 2018). Yogyakarta: Atlantis Press. Retrieved from https://www.atlantispress.com/proceedings/iceri-18/125912798

Arini, F. D., Choiri, A. S., \& Sunardi. (2017). The Use of Comic As a Learning Aid To Improve Learning Interest of Slow Learner Student. European Journal of Special Education Research, 2(1), 71-78. https://doi.org/10.5281/zenodo.221004

Ariyanto, A., \& Laksana, S. (2018). Learning Social Sciences With Comic Strip. Westech, 8. https://doi.org/10.4108/eai.8-12-2018.2283992

Batool, S., Nadeem, A., \& Asif, M. (2018). Managing Higher Education Quality Enhancement in Pakistan through Communication Skill to achieve International Opportunities. Journal of Managerial Sciences, XII(1), 37-48.

Chung, B. S., Park, E., Kim, S.-H., Cho, S., \& Chung, M. S. (2016). Comic Strips to Accompany Science Museum Exhibits. Journal of Education and Learning, 5(4), 141. https://doi.org/10.5539/jel.v5n4p141

Chung, Y., Yoo, J., Kim, S. W., Lee, H., \& Zeidler, D. L. (2016). Enhancing Students' Communication Skills in the Science Classroom Through Socioscientific Issues. International Journal of Science and Mathematics Education, 14(1), 1-27. https://doi.org/10.1007/s10763-014-9557-6 
Daulay, M. I., Ananda, A., Anwar, S., \& Fatimah, S. (2019). Developing Comics-Based Social Sciences-History Teaching Materials. 1st International Conference of Innovation in Education (ICoIE 2018), 178(ICoIE 2018), 77-83. https://doi.org/10.2991/icoie-18.2019.19

Dewantara, D, Febrianti, Wati, M., \& Mastuang. (2019). Development of simple machines props to train student's science process skills. Journal of Physics: Conference Series, 1171(1). https://doi.org/10.1088/1742-6596/1171/1/012017

Dewantara, D, Mahtari, S., Misbah, M., \& Haryandi, S. (2019). Student Responses in Biology Physics Courses Use Worksheets Based on Scientific Literacy. Prisma Sains : Jurnal Pengkajian Ilmu Dan Pembelajaran Matematika Dan IPA IKIP Mataram, 7(2), 192197.

Fadhila, S. F. N., \& Widodo, W. (2019). The Development of Education Comic as Science Materials for Lower Secondary on Topic of Light and Optic to Improve Student Learning Outcomes. E-Journal Pensa, 7(2), 262-267.

Greenstein, L. (2013). Assessing 21st Century Skills. Corwin Press.

Hake, R. R. (1998). Interactive-Engagement versus Traditional Methods: A Six-ThousandStudent Survey of Mechanics Test Data for Introductory Physics Courses. American Journal of Physics, 66, 1-27.

Hardianti, R. D., Taufiq, M., \& Pamelasari, S. D. (2017). The development of alternative assessment instrument in web - based scientific communication skill in science education seminar course. Jurnal Pendidikan IPA Indonesia, 6(1), 123-129. https://doi.org/10.15294/jpii.v6i1.7885

Haroky, F., Nikmah, S., Wilujeng, I., Jumadi, \& Kuswanto, H. (2019). Android-Assisted Physics Comic Learning to Train Students' Conceptual Understanding of Newton's Gravity. Journal of Physics: Conference Series, 1233(012045). https://doi.org/10.1088/1742-6596/1233/1/012045

Hartini, S., Misbah, M., Dewantara, D., Oktovian, R. A., \& Aisyah, N. (2017). Developing Learning Media Using Online Prezi into Materials about Optical Equipments. Jurnal Pendidikan IPA Indonesia, 6(2), 313-317.

Hidayah, I. N., \& Fathimatuzzahra. (2019). Development of Math Comic Learning Media on the Subject of Algebraic Expressions for Seventh Grade of Junior High School Students. Journal of Physics: Conference Series, 1227(012029). https://doi.org/10.1088/1742-6596/1227/1/012029

Kamil, A., Komariah, E., \& Yuliana. (2017). The Use of Comic to Improve Students' Reading Comprehension Skill at Junior High School. Research in English and Education (READ), 2(3).

Krishnan, S., \& Othman, K. (2016). The Effectiveness Of Using Comic To Increase Pupils' Achievements And Higher Order Thinking Skills In Science. International Journal of English and Education, 5(3), 281-293.

Lin, S. F., \& Lin, H. S. (2016). Learning nanotechnology with texts and comics: the impacts on students of different achievement levels. International Journal of Science Education, 38(8), 1373-1391. https://doi.org/10.1080/09500693.2016.1191089

Mahtari, S., Wati, M., Hartini, S., Misbah, M., \& Dewantara, D. (2020). The effectiveness of the student worksheet with $\mathrm{PhET}$ simulation used scaffolding question prompt. 
Journal of Physics: Conf. Series, 1422(012010), 1-7. https://doi.org/10.1088/17426596/1422/1/012010

Marlina, W., \& Jayanti, D. (2019). 4C dalam Pembelajaran Matematika untuk Menghadapi Era Revolusi Industri 4.0. Prosiding Sendika, 5(1), 392-396.

Maryani, I., \& Amalia, L. (2018). The Development of Science Comic to Improve Student's Understanding in Elementary School. Jurnal Inovasi Pendidikan IPA, 4(1), 75-82. https://doi.org/10.21831/JIPI.V4I1.21076

McGrail, E., Rieger, A., Doepker, G., \& McGeorge, S. (2018). Pre-Service Teachers' Perspectives on How the Use of TOON Comic Books during Guided Reading Influenced Learning by Struggling Readers. SANE Journal: Sequential Art Narrative in Education, 2(3).

Misbah, M., Dewantara, D., Hasan, S. M., \& Annur, S. (2018). The Development of Student Worksheet By Using Guided Inquiry Learning Model To Train Student'S Scientific Attitude. Unnes Science Education Journal, 7(1), 19-26. https://doi.org/10.15294/USEJ.V7I1.15799

Munawwaroh, E. L., Priyono, B., \& Ningsih, M. R. (2018). The Influence of Science Comic Based Character Education on Understanding the Concept and Students' Environmental Caring Attitude on Global Warming Material. Journal of Biology Education, 7(2), 167-173. https://doi.org/10.15294/jbe.v7i2.24257

Muzumdar, J. (2016). Use of A Comic Book to Assist Student Learning of Dimensions of Patient-Centered Care. INNOVATIONS in Pharmacy, 7(4). https://doi.org/10.24926/iip.v7i4.464

Nikmah, S., Haroky, F., Jumadi, Wilujeng, I., \& Kuswanto, H. (2019). Development of Android Comic Media for the Chapter of Newton's Gravity to Map Learning Motivation of Students. Journal of Physics: Conference Series, 1233(1). https://doi.org/10.1088/1742-6596/1233/1/012051

Prabowo, C. A., \& Ariani, N. L. (2018). Meningkatkan Keterampilan Komunikasi Oral Mahasiswa Melalui Strategi Pembelajaran Think Pair Share. BIOEDUKASI (Jurnal Pendidikan Biologi), 9(1), 57. https://doi.org/10.24127/bioedukasi.v9i1.1384

Putri, R. A., Fida, R., \& Wasis, W. (2018). The Development of Biology Comic Education with Compare and Contrast Learning $(\mathrm{CaC})$ Method to Improve 10 th Grade Students' Literacy. Journal of Physics: Conference Series, 1108(1). https://doi.org/10.1088/1742-6596/1108/1/012028

Raniah, D., Efendi, R., Liliawati, W., Studi, P., Fisika, P., Pendidikan, F., \& Pengetahuan, I. (2018). Profil Keterampilan Abad 21 pada Pembelajaran Project Based Learning ( PjBL ) Materi Gelombang Bunyi. Prosiding Seminar Nasional Fisika (SINAFI), 1924.

Ridwan, S. (2019). Intellectual Capital dan Knowledge Management dalam Inovasi dan Kreasi Media Pembelajaran Berbasis Kemampuan 4C dan Literasi. Proceedings of the ICECRS, 2(1), 75. https://doi.org/10.21070/picecrs.v2i1.2414

Susanti, D., \& Risnanosanti. (2019). Pengembangan Buku Ajar untuk Menumbuhkembangkan Kemampuan 4C ( Critical , Creative , Collaborative , Communicative ) melalui Model PBL pada Pembelajaran Biologi di SMP 5 Seluma. Prosiding Seminar Nasional Sains Dan Enterpreneurship VI, 1-9. 
Tribull, C. M. (2017). Sequential Science: A Guide to Communication Through Comics. Annals of the Entomological Society of America, 110(5), 457-466. https://doi.org/10.1093/aesa/sax046

Utami, R. Sumarni, W. Habibah, N. A. (2017). The use of comic as a learning medium for ecology. Unnes Science Education Journal, 6(1), 1496-1502. https://doi.org/http://dx.doi.org/10.15294/usej.v3i2.3349

Widoyoko, E. P. (2016). Evaluasi program pembelajaran. Yogyakarta: Pustaka Pelajar.

Yulian, V. N. (2018). Developing Teaching Materials Using Comic Media to Enhance Students' Mathematical Communication. IOP Conference Series: Materials Science and Engineering, 335(012110). https://doi.org/10.1088/1757-899X/335/1/012110

Zhang-Kennedy, L., Baig, K., \&Chiasson, S. (2017). Engaging children about online privacy through storytelling in an interactive comic.HCI 2017: Digital Make Believe Proceedings of the 31st International BCS Human Computer Interaction Conference, HCI 2017, 2017-July, 1-11. https://doi.org/10.14236/ewic/HCI2017.45 